\title{
Biodegradation a-endosulfan and a-cypermethrin by Acinetobacter schindleri B7 isolated from the microflora of grasshopper (Poecilimon tauricola)
}

Ozlem Gur Ozdal ( $\sim$ ozlemgur55@gmail.com )

Ataturk University https://orcid.org/0000-0003-3460-3638

Omer Faruk ALGUR

Ataturk University

\section{Research Article}

Keywords: Acinetobacter schindleri, biodegradation, a-cypermethrin, a-endosulfan, grasshopper

Posted Date: March 6th, 2021

DOl: https://doi.org/10.21203/rs.3.rs-282404/v1

License: (c) (i) This work is licensed under a Creative Commons Attribution 4.0 International License.

Read Full License 


\section{Abstract}

Extensive applications of pesticides have led to the contamination of ecosystem. Therefore, the isolation of new pesticide degrading bacteria is important. For the biodegradation of a-endosulfan and acypermethrin, new bacteria isolates were isolated from grasshopper (Poecilimon tauricola). According to different tests, these isolated bacteria were identified as Pseudomonas aeruginosa B5, Acinetobacter johnsonii B6, Acinetobacter schindleri B7, Bacillus megaterium B9 and Brevibacillus parabrevis B12. The first two of these bacteria have been isolated as those that can use only a-endosulfan and the last two only use a-cypermethrin. Moreover, $A$. schindleri $\mathrm{B} 7$ was determined to be able to degrade both pesticides. When glucose was added to non-sulfur medium containing a-endosulfan (100 mg/L) and minimal salt medium containing a-cypermethrin $(100 \mathrm{mg} / \mathrm{L})$, both pesticide degradation and bacterial growth was increased. As a result, $A$. schindleri, a new gram negative bacterium, can inevitably be used in the biological treatment of environments exposed to pesticides.

\section{Introduction}

Pesticides are used against pests in order to obtain more products and their use is increasing day by day. These chemicals, which are toxic to the environment, are widely used for the protection of stored products outside agricultural areas, against insects and weeds damaging forest trees (Jiang et al. 2019; Gao et al. 2020). According to their chemical structure, the most important pesticide groups are carbamates, organochlorinates, organophosphorus and synthetic pyrethroids. Endosulfan is an insecticide in the cyclodine group of organochlorinated pesticides (Ozdal et al. 2016). The use of endosulfan is prohibited in many countries and in our country. However, studies have shown that endosulfan is produced illegally and continues to be used out of control (Gao et al. 2020). Endosulfan and disintegration products have been identified in atmospheres, soil, food products, groundwater and surface waters. It can remain intact in nature for a long time and threatens the environment and public health. It has immunosuppressive, neurotoxicity, hepatotoxicity, respiratory toxicity, reproductive toxicity, and mutagenic effects in mammals (Sebastian Raghavan 2017; Ahmad 2020; Nazir et al. 2021). Cypermethrin is commercially available synthetic pyrethroid and generally used to control insects and pests in many environments. Synthetic pyrethroids usually have less toxicity for organisms than organophosphate and organochlorines. However, they have negative effects on the environment and human health due to their high rate of use (Gur et al. 2014; Aguila-Torres et al. 2020).

The breakdown of pesticide in nature can be biotic or abiotic conditions. Pesticide is biodegradable in nature, this is a result of microorganism activities. Endosulfan can be used by microorganisms as a source of carbon and/or sulfur (Mudhoo et al. 2019; Rodriguez-Peña et al. 2020). Also, a-cypermethrin as the sole carbon source for growth and energy metabolism can be used by microorganisms (Gur et al. 2014; Ramya and Vasudevan 2020).

Insects are the richest species in living organisms. Bacteria compose a significant portion of the microbial flora of insects. The symbiotic interactions between microorganisms and insects can be in very 
different ways (defend against pathogens, produce enzymes that aid digestion, decomposition of harmful compounds) (Paniagua Voirol et al. 2018). Insect microflora forms a suitable habitat for microorganisms that produce some important enzymes. The effects of insect microflora, especially in the transport of pathogen and antibiotic resistant microorganisms have been investigated (Pai et al. 2005). Insect guts provide a suitable medium for gene transfer between bacteria. Microorganisms can adapt to new environments by acquiring different characteristics with horizontal gene transfer, conjugative plasmids and simple mutations (Itoh et al. 2018; Pietri et al. 2018; Ramakrishnan et al. 2019). According to this information, it is highly possible to isolate pesticide resistant microorganisms from insect intestines.

Generally, bacterial strains such as Pseudomonas, Bacillus, Rhodococcus, Stenotrophomonas, Alcaligenes, Serratia and Streptomyces have been used in the breakdown of many pesticides (John et al. 2016; Ozdal et al. 2016; Gaonkar et al. 2019; Jiang et al. 2019). Acinetobacter schindleri is a Gram negative, nonmotile, coccobacilli, nonspore forming and aerobic bacterium. $A$. schindleri can be found in different environments and is seldomly used for biodegradation of pesticides. Some studies indicate that A. schindleri can biodegrade different chemicals such as polyhydroxyalkanoates (Boyandin et al. 2012), organic pollutants decachlorobiphenyl (Zenteno-Rojas et al. 2019) and acetate (Sigala et al. 2017). The aim of this study is to biodegrade a-endosulfan and a-cypermethrin using $A$. schindleri B7 isolated from insect flora and to determine their degradation products.

\section{Materials And Methods}

\section{Chemicals}

Pesticides (a-endosulfan and a-cypermethrin) and their degradation products were of analytical purity and they were dissolved in acetone.

\section{Isolation of endosulfan degrading microorganisms}

Grasshoppers (Poecilimon tauricola Ramme 1951, Orthoptera) were taken from farmland (Uzunyayla Village, Erzurum, Turkey) contaminated with pesticide. The grasshoppers were individually placed in sterile capped vials containing $70 \%$ ethanol and gently shaken for 3 minutes and then washed several times with sterile distilled water for surface sterilization (Okay et al. 2013; Ozdal et al. 2016). After alcohol removal with sterile physiological water (SFS), they were crushed in a sterile mortar with SFS and homogenized. Serial dilutions of homogenate were prepared and $0.1 \mathrm{~mL}$ of liquid was added into nonsulfur medium (NSM) containing a-endosulfan (100 mg/L) and minimal salt medium (MSM) containing a-cypermethrin $(100 \mathrm{mg} / \mathrm{L})$. Cultures incubated for 7 days at $30^{\circ} \mathrm{C}$ and $150 \mathrm{rpm}$ were transferred to the media under the same conditions with $0.1 \mathrm{~mL}$ and this process was repeated every 7 days and continued for 21 days. Then, $0.1 \mathrm{ml}$ of the enrichment culture was taken and inoculated on the prepared solid NSM and MSM. The petri dishes were incubated at $30{ }^{\circ} \mathrm{C}$ and at the end of 72 hours, the colonies of all different characteristics, primarily those that grow densely, were transferred to TSA medium and isolated. To prepare solid media, agar ( $15 \mathrm{~g} / \mathrm{L})$ was added to NSM and MSM. All media were sterilized at $121^{\circ} \mathrm{C}$ 
for 15 minutes and after cooling to $45^{\circ} \mathrm{C}$, a-endosulfan and a-cypermethrin were added. The contents of NSM and MSM are given in Table 1.

\section{Identification of endosulfan degrading microorganisms}

Species growing on NSM agar containing a-endosulfan and MSM agar containing a-cypermethrin were defined by the morphology and biochemical methods. Isolated bacteria were also identified according to fatty acid methyl ester (FAME) profiles using the MIS software package (Ozdal et al. 2016). The isolate that degraded both pesticides was determined by 16S rDNA analysis (Gur et al. 2014).

\section{Preparation of uniform bacterial inoculum}

Tryptic Soy Broth was used to reproduce bacteria. Bacteria grown in broth medium were centrifuged for 5 minutes at $5000 \mathrm{rpm}$, washed several times with $0.9 \%$ sterile physiological water and adjusted to optical density $\left(\mathrm{OD}_{600}\right)$ of 0.5 .

\section{Biodegradation of a- endosulfan and a-cypermethrin by Acinetobacter schindleri B7}

$100 \mathrm{mg} / \mathrm{L}$ a-endosulfan and a-cypermethrin were added into $100 \mathrm{~mL}$ of NSM and MSM in $250 \mathrm{~mL}$ conical flasks, and $1 \mathrm{~mL}$ of inoculum $\left(\mathrm{OD}_{600} 0.5\right)$ was inoculted (Ozdal et al. 2017). The flasks were shaken at $150 \mathrm{rpm}$ at $30^{\circ} \mathrm{C}$ for 10 days and a pH of 8.0. The effects of glucose on bacterial growth, biodegradation of pesticides and degradation products were also investigated.

\section{Analytical methods}

HPLC was used for the determination of pesticides (a-cypermethrin and a-endosulfan) and their biodegradation products. At the end of certain incubation periods, the samples were extracted with ethyl acetate $(1: 1, v / v)$. Upper phases were dried with sodium sulfate anhydrous, and concentrated with a rotary evaporator. The biodegradation samples of a-endosulfan were analyzed by HPLC with ODS C18 Hypersil Column $(250 \times 4.6 \mathrm{~mm}, 5 \mu \mathrm{m})$ equipped with UV-VIS detector at $214 \mathrm{~nm}$. A mixture containing acetonitrile/water (70:30, v/v) was used as the mobile phase (Ozdal et al. 2017). The retention times were as follows: a-endosulfan, $5.323 \mathrm{~min}$; endosulfan sulfate, $7.873 \mathrm{~min}$; endosulfan ether, $8.976 \mathrm{~min}$; endosulfan lactone, $10.035 \mathrm{~min}$; endosulfan diol, $12.086 \mathrm{~min}$, respectively. The biodegradation samples of a-cypermethrin were analyzed by HPLC using a SUPELCOSIL C18 DB column $(250 \times 4.6 \mathrm{~mm}, 5 \mu \mathrm{m})$ with a acetonitrile:water (85:15) mobile phase. The solutes were detected using a UV-Vis detector at 235 $\mathrm{nm}$ (Gur et al. 2014). The retention times were as follows: a-cypermethrin, 4.603 min; 3-phenoxybenzoic acid, 2.119 min; phenol, 8.298 min; 3-phenoxybenzaldehyde, $2.273 \mathrm{~min}$; cis,cis-muconic acid, $3.573 \mathrm{~min}$, respectively. Bacterial growth was determined spectrophotometrically at $600 \mathrm{~nm}$.

\section{Results}

Five bacteria capable of breaking down the a-endosulfan and/or a-cypermethrin were successfully isolated from NSM-agar or MSM-agar plates (Table 2). Among these 5 bacterial isolates, 3 were Gram- 
negative. All the isolates were catalase positive. Of these isolates, 2 were oxidase positive, 4 were rod and 1 was cocobacilli. According to biochemical test and physical properties, a-endosulfan degrading isolates were identified as Pseudomonas aeruginosa B5, Bacillus megaterium B9, Acinetobacter schindleri B7 and a-cypermethrin degrading isolates were identified as Acinetobacter johnsonii B6, Acinetobacter schindleri $\mathrm{B} 7$ and Brevibacillus parabrevis B12. A. schindleri B7, which can use both pesticides among the isolated bacteria, was used in subsequent studies.

Genetic analysis of $A$. schindleri B7 strain causing the a-endosulfan and a-cypermethrin biodegradation was performed. A 910-bp 16S rRNA sequence of the strain was screened with BLAST search program of GenBank's. The nucleotide sequence was registered at GenBank with accession number KC453989. A phylogenetic tree was shown in Figure 1. According to these results, this isolate was identified as $A$. schindleri strain B7.

It was determined that $A$. schindleri B7 utilized a -endosulfan as sole sulfur and carbon source, and acypermethrin as the sole carbon source. In different NSM (a- endosulfan + glucose, a-endosulfan, and glucose), bacterial growth were significantly altered. Further bacterial growth $\left(\mathrm{OD}_{600} 1.74\right)$ was determined when only glucose was added to NSM. Bacterial growth in the presence of a-endosulfan and glucose was $1.58\left(\mathrm{OD}_{600}\right)$, and it decreased up to $0.61\left(\mathrm{OD}_{600}\right)$ when glucose was removed (Figure $\left.2 \mathrm{a}\right)$.

In different MSM (a-cypermethrin + glucose, a-cypermethrin, and glucose), bacterial growth were significantly changed. Maximum bacterial growth $\left(\mathrm{OD}_{600} 1.75\right)$ was achieved with the supplement of glucose to MSM. Bacterial growth in the presence of-cypermethrin and glucose was $1.57\left(\mathrm{OD}_{600}\right)$ and dropped to $0.59\left(\mathrm{OD}_{600}\right)$ when glucose was not added (Figure $\left.2 \mathrm{~b}\right)$.

The percentage of biodegradation of a -endosulfan and a-cypermethrin was determined with HPLC on the tenth day. It was observed that the a-endosulfan biodegradation rate for $A$. schindleri B7 was different at the same incubation period when inoculated in NSM supplemented with or without glucose. As seen in Figure $3 a$, the addition of glucose increased biodegradation of a-endosulfan. In the absence of glucose, the a-endosulfan biodegradation efficiency of $A$. schindleri B7 was $59.74 \%$ at the end of 10 days. The addition of $1 \mathrm{~g} / \mathrm{L}$ of glucose increased a-endosulfan biodegradation efficiency to $67.31 \%$, which corresponds to an increase of $12.72 \%$. As shown in Figure 3a, endosulfan diol, endosulfan ether and endosulfan lactone were defined as degradation products in the biodegradation of a-endosulfan by $A$. schindleri B7. Intermediate products ratios increased when glucose was added to NSM. Endosulfan diol was determined as the main metabolite in both media. Also, endosulfan sulfate, a toxic metabolite, was not formed in both media.

As seen in Figure $3 \mathrm{~b}$, it was determined that $A$. schindleri B7 biodegraded a-cypermethrin $68.4 \%$ in glucose-added medium and $59.53 \%$ in glucose-free medium. The addition of glucose $(1 \mathrm{~g} / \mathrm{L})$ increased the a-cypermethrin biodegradation efficiency to $68.4 \%$, corresponding to an increase of $14.90 \%$. As a result of a-cypermethrin biodegradation, in the glucose containing medium, more muconic acid, 3- 
phenoxybenzoic acid and 3-phenoxybenzaldehyde were formed compared to the medium without glucose. But, less phenol was formed in glucose containing medium.

When Figure 2 and Figure 3 are analyzed together, presence of glucose enhanced the growth of the A. schindleri B7 and biodegradation of $a$-endosulfan and a-cypermethrin. The increase in pesticides biodegradation was determined to be related to the increase in bacterial density.

\section{Discussion}

Insects are in close interaction with bacteria (Jahnes and Sabree 2020; Ozdal and Algur 2020). Therefore, insects are the source for the isolation of many industrially important microorganisms. Serratia marcescens M0-1 isolated from grasshopper has both chitinase activity (Okay et al. 2013) and the ability to produce prodigiosin pigment (Kurbanoglu et al. 2015) which has antimicrobial, antioxidant and anticancer properties. Also, Pseudomonas aeruginosa OG1 isolated from cockroaches (Blatta orientalis) can produce pyocyanin pigment (Ozdal, 2019) and rhamnolipid biosurfactants (Ozdal et al. 2017b). Similarly, the digestive systems of different animal groups are also rich in microorganisms (Das et al. 2014).

In this study, a-endosulfan and a-cypermethrin degradation was achieved by utilizing bacteria isolated from grasshopper microflora (Table 2). These bacteria were identified as $P$. aeruginosa $\mathrm{B} 5, A$. schindleri $\mathrm{B} 7, B$. megaterium B9, B. parabrevis B12 and A. johnsonii B6. These species have previously been used in the studies of degradation of different toxic compounds (Ozdal et al. 2016; Ozdal and Algur 2020).

In recent years, bacteria isolated from insect flora have been indicated to be a significant source to biodegradation of pesticide (Table 3). Isolation of microorganisms that break down pesticides is made from different environments where pesticides are used (Gaonkar et al. 2019). Many studies have shown that pesticide-resistant insects' microbiota provides a favorable environment for the isolation of potential microorganisms for biodegradation against specific pesticides (Ozdal et al. 2016; Itoh et al. 2018; Pietri et al. 2018; Pietri and Liang 2018). Some symbiotic microorganisms mediate the detoxification of pesticides, providing pesticide resistance to their hosts (Cheng et al. 2017).

It has been known that a carbon source (at low concentrations) other than the target chemical affects the rate of degradation of organic compounds. Of course, the presence of a carbon source in the growth medium significantly affects bacterial metabolism. According to results, the addition of glucose accelerated the growth of the bacteria as well as the biodegradation process (Figure 2). The increase in biodegradation of the pesticide was found to be due to the increase in cell concentration (Gur et al. 2014; John et al. 2016).

Endosulfan is generally biodegraded by oxidation and hydrolysis pathways. In the oxidation pathway, endosulfan sulphate is formed. In the hydrolysis pathway, endosulfan diol, endosulfan ether and endosulfan lactone, which are less toxic than endosulfan, are formed (Mudhoo et al. 2019). Microorganisms that produce endosulfan sulphate are not suitable for bioremediation applications 
because endosulfan sulphate is very toxic to organisms. Some microorganisms degrade endosulfan through oxidation by forming endosulfan sulphate. It is thought to be very valuable that bacterial species carrying the hydrolytic pathway for degradation of endosulfan. Many bacteria (Pseudomonas, Rhodococcus, Stenotrophomonas, Ochrobacterum and Alcaligenes) have been found to use the hydrolytic pathway for endosulfan degradation (Mudhoo et al. 2019). Ozdal et al. (2017) reported the biodegradation of a-endosulfan by Stenotrophomonas maltophilia OG2 (isolated from the cockroaches, Blatta orientalis) with the degradation efficiency of $81.5 \%$ in 10 days. a-endosulfan was converted to endosulfan diol, endosulfan ether and endosulfan lactone by bacterial isolate OG2. According to these results, $A$. schindleri B7 breaks down the a-endosulfan by hydrolysis (non-oxidative) which is less toxic pathway (Figure 3a).

1. schindleri B7 degraded a-cypermethrin to 3-phenoxybenzaldehyde, 3-phenoxybenzoic acid, phenol and muconic acid, respectively (Figure 3b). Similar results were reported for Micrococcus sp. strain CPN 1 (Tallur et al., 2008) and S. maltophilia starin OG2 (Ozdal et al. 2014). It can be said that the acypermethrin biodegradation pathway in A. schindleri $\mathrm{B} 7$ is similar to that of these researchers. According to a-cypermethrin biodegradation pathway, A. schindleri B7 can degrade harmful metabolites such as 3-phenoxybenzoic acid and phenol.

In conclusion, it was determined that pesticide-degrading new bacteria can be isolated from insects and used in biodegradation studies. The newly isolated $A$. schindleri B7 break down the a-endosulfan in a less toxic hydrolytic route. It is also important that this bacterium breaks down the synthetic pyrethroid acypermethrin. This isolated bacterium may be important in the microbiological treatment of pesticides contaminated environments. Many insects living in pesticide contaminated environments should be investigated to isolate new pesticide-degrading microorganism.

\section{Declarations}

\section{Funding information}

The authors are grateful to Ataturk University Scientific Research Project Fund for financial support.

\section{Authors' contributions}

OGO performed the study design, development and methodology, the collection of all data, and the data analysis/interpretation, and wrote all the manuscript. OFA performed the study design and data analysis.

\section{Conflict of interest}

The authors declare that they have no conflict of interest.

\section{References}


Aguila-Torres P, Maldonado J, Gaete A, Figueroa J, González A, Miranda R, González-Stegmaier R, Martin C, González M (2020) Biochemical and genomic characterization of the cypermethrin-degrading and biosurfactant producing bacterial strains isolated from marine sediments of the Chilean Northern Patagonia. Mar Drugs 18:252. https://doi.org/10.3390/md18050252

Ahmad KS (2020). Remedial potential of bacterial and fungal strains (Bacillus subtilis, Aspergillus niger, Aspergillus flavus and Penicillium chrysogenum) against organochlorine insecticide Endosulfan. Folia Microbiol 65:801-81. https://doi.org/10.1007/s12223-020-00792-7

Boyandin AN, Prudnikova SV, Filipenko ML, Khrapov EA, Vasil'ev AD, Volova TG. (2012) Biodegradation of polyhydroxyalkanoates by soil microbial communities of different structures and detection of PHA degrading microorganisms. Appl Biochem Microbiol 48:28-36.

https://doi.org/10.1134/S0003683812010024

Cheng D, Guo Z, Riegler M, Xi Z, Liang G, Xu Y (2017). Gut symbiont enhances insecticide resistance in a significant pest, the oriental fruit fly Bactrocera dorsalis (Hendel). Microbiome 5:13 https://doi.org/10.1186/s40168-017-0236-z

Das P, Mandal S, Khan A, Manna SK, Ghosh K (2014) Distribution of extracellular enzyme-producing bacteria in the digestive tracts of 4 brackish water fish species. Turk J Zool 38(1):79-88. https://doi.org/10.3906/zoo-1205-3

de Almeida LG, de Moraes LAB, Trigo JR, Omoto C, Cônsoli FL (2017) The gut microbiota of insecticideresistant insects houses insecticide-degrading bacteria: A potential source for biotechnological exploitation. PloS One 12(3):e0174754. https://doi.org/10.1371/journal.pone.0174754

Gaonkar O, Nambi IM, Suresh Kumar G (2019) Biodegradation kinetics of dichlorvos and chlorpyrifos by enriched bacterial cultures from an agricultural soil. Bioremediat J 23(4):259-276.

https://doi.org/10.1080/10889868.2019.1671791

Gur O, Ozdal M, Algur OF (2014) Biodegradation of the synthetic pyrethroid insecticide a-cypermethrin by Stenotrophomonas maltophilia OG2. Turk J Biol 38(5): 684-689. https://doi.org/10.3906/biy-1402-10

Gur Ozdal O, Algur OF (2020) Isolation and identification of the pyrethroid insecticide deltamethrin degrading bacteria from insects. Eur J Sci Technol (18):905-910. https://doi.org/10.31590/ejosat.677008

Itoh H, Tago K, Hayatsu M, Kikuchi Y (2018) Detoxifying symbiosis: microbe-mediated detoxification of phytotoxins and pesticides in insects. Nat Prod Rep 35(5):434-454. https://doi.org/10.1039/C7NP00051K Jahnes BC, Sabree ZL (2020) Nutritional symbiosis and ecology of host-gut microbe systems in the Blattodea. Curr Opin Insect Sci 39:35-41 https://doi.org/10.1016/j.cois.2020.01.001

Jiang B, Zhang N, Xing Y, Lian L, Chen Y, Zhang D, Li G, Sun G, Song Y (2019) Microbial degradation of organophosphorus pesticides: novel degraders, kinetics, functional genes, and genotoxicity 
assessment. Environ Sci Pollut Res26:21668-21681. https://doi.org/10.1007/s11356-019-05135-9

John EM, Sreekumar J, Jisha MS (2016) Optimization of chlorpyrifos degradation by assembled bacterial consortium using response surface methodology. Soil Sediment Contam 25:668-682. https://doi.org/10.1080/15320383.2016.1190684

Gao Y, Zheng H, Xia Y, Cai M (2020) Global scale distribution, seasonal changes and long-range transport potentiality of endosulfan in the surface seawater and air. Chemosphere, 260:127634. https://doi.org/10.1016/j.chemosphere.2020.127634

Kikuchi Y, Hayatsu M, Hosokawa T, Nagayama A, Tago K, Fukatsu T (2012) Symbiont-mediated insecticide resistance. Proc Natl Acad Sci 109:8618-8622. https://doi.org/10.1073/pnas.1200231109

Kurbanoglu EB, Ozdal M, Ozdal OG, Algur OF (2015) Enhanced production of prodigiosin by Serratia marcescens M0-1 using ram horn peptone. Braz J Microbiol 46:631-637. https://doi.org/10.1590/S1517838246246220131143

Malathi VM, More RP, Anandham R, Gracy GR, Mohan M, Venkatesan T, Samaddar S, Jalali SK, Sa T (2018) Gut bacterial diversity of insecticide-susceptible and-resistant nymphs of the brown planthopper Nilaparvata lugens Stål (Hemiptera: Delphacidae) and elucidation of their putative functional roles. J Microbiol Biotechnol 28:976-986. https://doi.org/10.4014/jmb.1711.11039

Mudhoo A, Bhatnagar A, Rantalankila M, Srivastava V, Sillanpää M (2019) Endosulfan removal through bioremediation, photocatalytic degradation, adsorption and membrane separation processes: a review. Chem Eng J 360:912-928. https://doi.org/10.1016/j.cej.2018.12.055

Nazir MS, Tahir Z, Hassan SU, Ali Z, Akhtar MN, Azam K, Abdullah MA (2021) Remediation of Pesticide in Water. In: Inamuddin, Ahamed MI, Lichtfouse E. (eds) Sustainable Agriculture Reviews 47. Springer, Cham. https://doi.org/10.1007/978-3-030-54712-7_8

Okay S, Ozdal M, Kurbanoglu EB (2013) Characterization, antifungal activity, and cell immobilization of a chitinase from Serratia marcescens M0-1. Turk J Biol 37:639-644. https://doi.org/10.3906/biy-1208-45

Ozdal M, Gurkok S, Ozdal OG (2017) Optimization of rhamnolipid production by Pseudomonas aeruginosa OG1 using waste frying oil and chicken feather peptone. 3 Biotech 7:117. https://doi.org/10.1007/s13205-017-0774-x

Ozdal M, Ozdal OG, Algur OF (2016) Isolation and characterization of a-endosulfan degrading bacteria from the microflora of cockroaches. Pol J Microbiol 65:63-68.

https://doi.org/10.5604/17331331.1197325

Ozdal M, Ozdal OG, Algur OF, Kurbanoglu EB (2017) Biodegradation of a-endosulfan via hydrolysis pathway by Stenotrophomonas maltophilia OG2. 3 Biotech 7:113. https://doi.org/10.1007/s13205-0170765-y 
Ozdal M, Ozdal OG., Sezen, A., Algur, O. F., Kurbanoglu, E. B. (2017). Continuous production of indole-3acetic acid by immobilized cells of Arthrobacter agilis. 3 Biotech 7:23. https://doi.org/10.1007/s13205017-0605-0

Ozdal OG, Algur, O. F (2020) Isolation and identification of the pyrethroid insecticide deltamethrin degrading bacteria from insects. European Journal of Science and Technology (18):905-910. https://doi.org/10.31590/ejosat.677008

Ozdal OG, Ozdal M, Algur OF, Sezen A (2016) Isolation and identification of a-Endosulfan degrading bacteria from insect microflora. TURJAF 4:248-254. https://doi.org/10.24925/turjaf.v4i4.248-254.472

Pai Hh, Chen WC, Peng CF. 2005. Isolation of bacteria with antibiotic resistance from household cockroaches (Periplaneta americana and Blattella germanica). Acta Trop 93:259-265. https://doi.org/10.1016/j.actatropica.2004.11.006

Paniagua Voirol LR, Frago E, Kaltenpoth M, Hilker M, Fatouros NE (2018) Bacterial symbionts in Lepidoptera: Their diversity, transmission, and impact on the host. Front Microbiol 9:556. https://doi.org/10.3389/fmicb.2018.00556

Pietri JE, Liang D (2018) The links between insect symbionts and insecticide resistance: causal relationships and physiological tradeoffs. Ann Entomol Soc Am 111:92-97. https://doi.org/10.1093/aesa/say009

Pietri JE, Tiffany C, Liang D (2018) Disruption of the microbiota affects physiological and evolutionary aspects of insecticide resistance in the German cockroach, an important urban pest. PLOS One 13(12):e0207985. https://doi.org/10.1371/journal.pone.0207985

Ramakrishnan B, Venkateswarlu K, Sethunathan N, Megharaj M (2019) Local applications but global implications: Can pesticides drive microorganisms to develop antimicrobial resistance? Sci Total Environ 654:177-189. https://doi.org/10.1016/j.scitotenv.2018.11.041

Ramya K, Vasudevan N (2020) Biodegradation of synthetic pyrethroid pesticides under saline conditions by a novel halotolerant Enterobacter /udwigii. Desalin Water Treat 173:255-266. https://doi.org/10.5004/dwt.2020.24791

Rodriguez-Peña M, Barrios JA, Becerril-Bravo E, Rodrigo MA, Barrera-Díaz C E (2020) Degradation of endosulfan by a coupled treatments in a batch reactor with three electrodes. Fuel 281:118741. https://doi.org/10.1016/j.fuel.2020.118741

Sebastian R, Raghavan SC (2017) Molecular mechanism of Endosulfan action in mammals. J Biosci 42:149-153. https://doi.org/10.1007/s12038-016-9655-4

Siddique T, Okeke BC, Arshad M, Frankenberg WT (2003) Enrichment and isolation of endosulfandegrading microorganisms. J Environ Qual 32:47-54. https://doi.org/10.2134/jeq2003.4700 
Sigala JC, Suárez BP, Lara AR, Le Borgne S, Bustos P et al. (2017) Genomic and physiological characterization of a laboratory-isolated Acinetobacter schindleri ACE strain that quickly and efficiently catabolizes acetate. Microbiology 163:1052-1064. https://doi.org/10.1099/mic.0.000488

Skaljac M, Kirfel P, Grotmann J, Vilcinskas A (2018) Fitness costs of infection with Serratia symbiotica are associated with greater susceptibility to insecticides in the pea aphid Acyrthosiphon pisum. Pest Manag Sci 74:1829-1836. https://doi.org/10.1002/ps.4881

Tallur PN, Megadi VB, Ninnekar HZ (2008) Biodegradation of cypermethrin by Micrococcus sp. strain CPN 1. Biodegradation 19:77-82. https://doi.org/10.1007/s10532-007-9116-8

Zenteno-Rojas A, Martinez-Romero E, Rincón-Molina Cl, Ruíz-Valdiviezo VM, Meza-Gordillo R (2019) Removal of high concentrations decachlorobiphenyl of earthworm Eisenia fetida and its symbiotic bacteria in a vermicomposting system. Water Air Soil Poll 230:116. https://doi.org/10.1007/s11270-0194170-5

Zhu Y, Li J, Yao K, Zhao N, Zhou K, Hu X, Zou L, Han X, Liu A, Liu S (2016) Degradation of 3phenoxybenzoic acid by a filamentous fungus Aspergillus oryzae M-4 strain with self-protection transformation. Appl Microbiol Biotechnol 100:9773-9786. https://doi.org/10.1007/s00253-016-7847-3

\section{Tables}

Table 1. Composition of non-sulfur medium (NSM) and minimal salt medium (MSM) $(\mathrm{pH}=8)$ 


\begin{tabular}{|lll|}
\hline & NSM & MSM \\
\hline $\mathrm{a}(\mathrm{g} / \mathrm{L})$ & & \\
\hline $\mathrm{K}_{2} \mathrm{HPO}_{4}$ & 0.225 & \\
\hline $\mathrm{KH}_{2} \mathrm{PO}_{4}$ & 0.225 & 1.5 \\
\hline $\mathrm{NH}_{4} \mathrm{Cl}$ & 0.225 & \\
\hline $\mathrm{MgCl}_{2} \cdot 6 \mathrm{H}_{2} \mathrm{O}$ & 0.845 & \\
\hline $\mathrm{CaCO}_{3}$ & 0.005 & \\
\hline $\mathrm{FeCl}_{2} \cdot 4 \mathrm{H}_{2} \mathrm{O}$ & 0.005 & \\
\hline$\left(\mathrm{NH}_{4}\right)_{2} \mathrm{SO}_{4}$ & & 2 \\
\hline $\mathrm{MgSO}_{4} \cdot 7 \mathrm{H}_{2} \mathrm{O}$ & & 0.2 \\
\hline $\mathrm{CaCl}_{2} \cdot 2 \mathrm{H}_{2} \mathrm{O}$ & & 0.01 \\
\hline $\mathrm{FeSO}_{4} \cdot 7 \mathrm{H}_{2} \mathrm{O}$, & & 0.001 \\
\hline $\mathrm{Na}_{2} \mathrm{HPO}_{4} \cdot 12 \mathrm{H}_{2} \mathrm{O}$ & & 1.5 \\
\hline $\mathrm{b}(\mathrm{mg} \mathrm{L})$ & & \\
\hline $\mathrm{MnCl}_{2} \cdot 4 \mathrm{H}_{2} \mathrm{O}$ & 198 & 198 \\
\hline $\mathrm{ZnCl}_{2}$ & 136 & 136 \\
\hline $\mathrm{CuCl}_{2} \cdot 2 \mathrm{H}_{2} \mathrm{O}$ & 171 & 171 \\
$\mathrm{CoCl}_{2} \cdot 6 \mathrm{H}_{2} \mathrm{O}$ & 24 & 24 \\
\hline $\mathrm{NiCl}_{2} \cdot 6 \mathrm{H}_{2} \mathrm{O}$ & 24 & 24 \\
\hline
\end{tabular}

Table 2. The morphological and biochemical characteristics of bacterial isolates of Poecilimon tauricola 


\begin{tabular}{|llllll|}
\hline Code & B5 & B6 & B7 & B9 & B12 \\
\hline $\begin{array}{l}\text { MIS } \\
\text { results }\end{array}$ & $\begin{array}{l}\text { Pseudomonas } \\
\text { aeruginosa }\end{array}$ & $\begin{array}{l}\text { Acinetobacter } \\
\text { johnsonii }\end{array}$ & $\begin{array}{l}\text { Acinetobacter } \\
\text { schindleri }\end{array}$ & $\begin{array}{l}\text { Bacillus } \\
\text { megaterium }\end{array}$ & $\begin{array}{l}\text { Brevibacillus } \\
\text { parabrevis }\end{array}$ \\
\hline Pigment & Blue-green & - & - & - & - \\
\hline Shape & Rod & Rod & Coccobacilli & Rod & Rod \\
Gram & - & - & - & + & + \\
Catalase & + & + & + & + & + \\
Oxidase & + & - & - & - & + \\
a ES & + & - & + & + & - \\
\hline a CP & - & + & + & - & + \\
\hline
\end{tabular}

Table 3. Bacteria isolated from insect flora for degradation of different pesticides 


\begin{tabular}{|c|c|c|c|}
\hline Pesticide & Insect & Bacteria & References \\
\hline Fenitrothion & $\begin{array}{l}\text { Bean bug, } \\
\text { Riptortus } \\
\text { pedestris }\end{array}$ & Burkholderia & $\begin{array}{l}\text { Kikuchi et } \\
\text { al. } 2012\end{array}$ \\
\hline $\begin{array}{l}\text { a-endosulfan, } a- \\
\text { cypermethrin }\end{array}$ & $\begin{array}{l}\text { Blatta } \\
\text { orientalis }\end{array}$ & $\begin{array}{l}\text { Pseudomonas, Stenotrophomonas, } \\
\text { Bacillus, Citrobacter, Acinetobacter }\end{array}$ & $\begin{array}{l}\text { Gur et al. } \\
2014\end{array}$ \\
\hline a-endosulfan & $\begin{array}{l}\text { Saga } \\
\text { ephippigera }\end{array}$ & $\begin{array}{l}\text { Acinetobacter Iwoffii, Pseudomonas } \\
\text { aeruginosa, Stenotrophomonas } \\
\text { maltophilia }\end{array}$ & $\begin{array}{l}\text { Gur Ozdal } \\
\text { et al. } 2016\end{array}$ \\
\hline a-endosulfan & $\begin{array}{l}\text { Forficula } \\
\text { auricularia }\end{array}$ & $\begin{array}{l}\text { S. maltophilia, Brevibacillus } \\
\text { choshinensis }\end{array}$ & $\begin{array}{l}\text { Gur Ozdal } \\
\text { et al. } 2016\end{array}$ \\
\hline a-endosulfan & $\begin{array}{l}\text { Sphodromantis } \\
\text { viridis }\end{array}$ & $\begin{array}{l}\text { Stenotrophomonas maltophilia, } \\
\text { Acinetobacter calcoaceticus, } \\
\text { Pseudomonas aeruginosa }\end{array}$ & $\begin{array}{l}\text { Gur Ozdal } \\
\text { et al. } 2016\end{array}$ \\
\hline a-endosulfan & $\begin{array}{l}\text { Gryllus } \\
\text { bimaculatus }\end{array}$ & $\begin{array}{l}\text { Pseudomonas aeruginosa, Bacillus } \\
\text { megaterium, Flavimonas oryzihabitans, }\end{array}$ & $\begin{array}{l}\text { Gur Ozdal } \\
\text { et al. } 2016\end{array}$ \\
\hline $\begin{array}{l}\text { Chlorpyrifos, } \\
\text { deltamethrin, lamda- } \\
\text { cyhalothrin, spinosad, } \\
\text { and luferunon }\end{array}$ & $\begin{array}{l}\text { Armyworm, } \\
\text { Spodoptera } \\
\text { frugiperda }\end{array}$ & $\begin{array}{l}\text { Enterococcus casseliflavus, } \\
\text { Enterococcus mundtii, Microbacterium } \\
\text { paraoxydans, Pseudomonas stutzeri, } \\
\text { Staphylococcus sciuri }\end{array}$ & $\begin{array}{l}\text { de } \\
\text { Almeida et } \\
\text { al. } 2017\end{array}$ \\
\hline Trichlorphon & $\begin{array}{l}\text { Oriental fruit } \\
\text { fly, Bactrocera } \\
\text { dorsalis }\end{array}$ & Citrobacter freundii & $\begin{array}{l}\text { Cheng et } \\
\text { al. } 2017\end{array}$ \\
\hline $\begin{array}{l}\text { Acephate, Imidacloprid, } \\
\text { thiamethoxam, } \\
\text { buprofezin, etofenprox }\end{array}$ & $\begin{array}{l}\text { Brown } \\
\text { planthopper } \\
\text { Nilaparvata } \\
\text { lugens }\end{array}$ & Morganella, Weissella, Enterococcus & $\begin{array}{l}\text { Malathi et } \\
\text { al. } 2018\end{array}$ \\
\hline $\begin{array}{l}\text { Imidacloprid, chlorpyrifos } \\
\text { methyl, methomyl, } \\
\text { cyantraniliprole and } \\
\text { spirotetramat }\end{array}$ & $\begin{array}{l}\text { Pea aphid } \\
\text { Acyrthosiphon } \\
\text { pisum }\end{array}$ & Serratia symbiotica & $\begin{array}{l}\text { Skaljac et } \\
\text { al. } 2018\end{array}$ \\
\hline Deltamethrin & $\begin{array}{l}\text { Grasshopper } \\
\text { Poecilimon } \\
\text { tauricola }\end{array}$ & $\begin{array}{l}\text { Pseudomonas aeruginosa, } \\
\text { Enterobacter intermedius, Serratia } \\
\text { marcescens, Bacillus atrophaeus }\end{array}$ & $\begin{array}{l}\text { Gur Ozdal } \\
\text { and Algur } \\
2020\end{array}$ \\
\hline
\end{tabular}

\section{Figures}




\section{Acinetobacter schindleri strain W1-2}

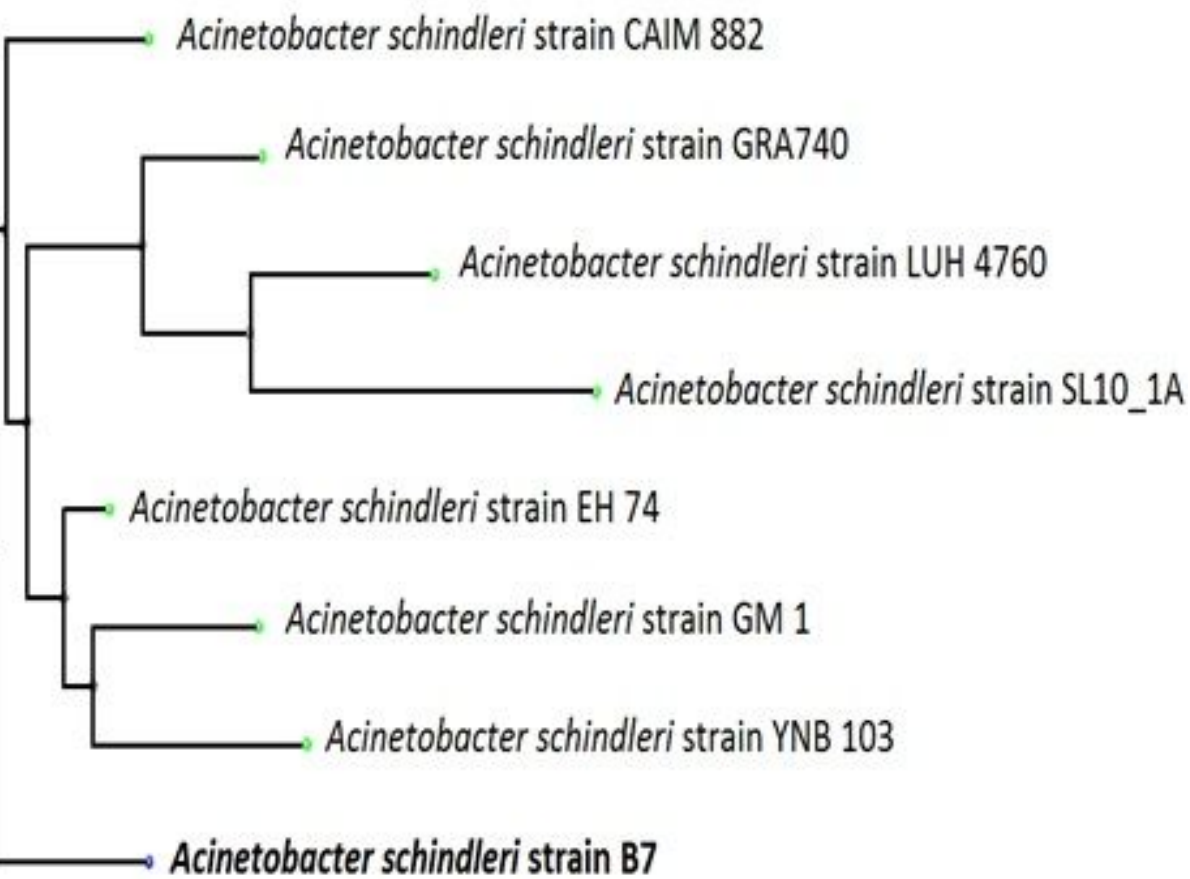

Figure 1

Phylogenetic tree depending on the 16S rRNA sequences of strain B7 and related species
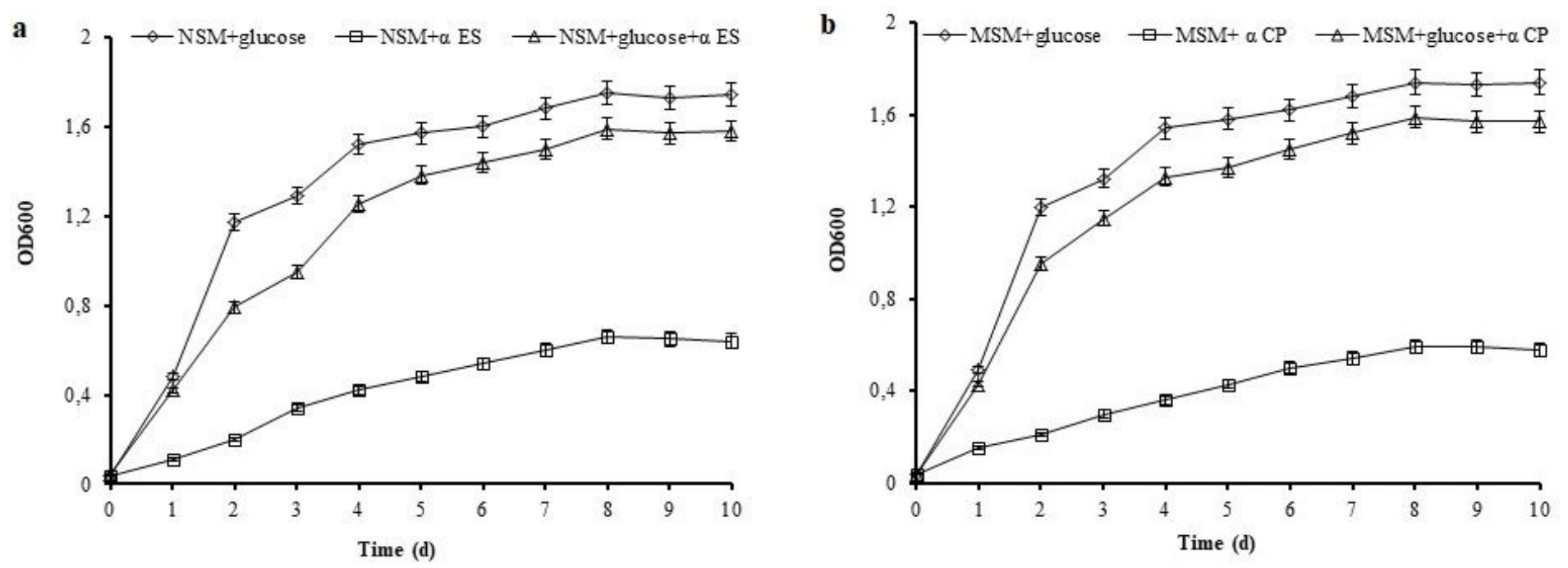

Figure 2

Effects of glucose addition on the growth of A. schindleri B7 in the presence and absence of $a-$ endosulfan (a) and a-cypermethrin (b) 

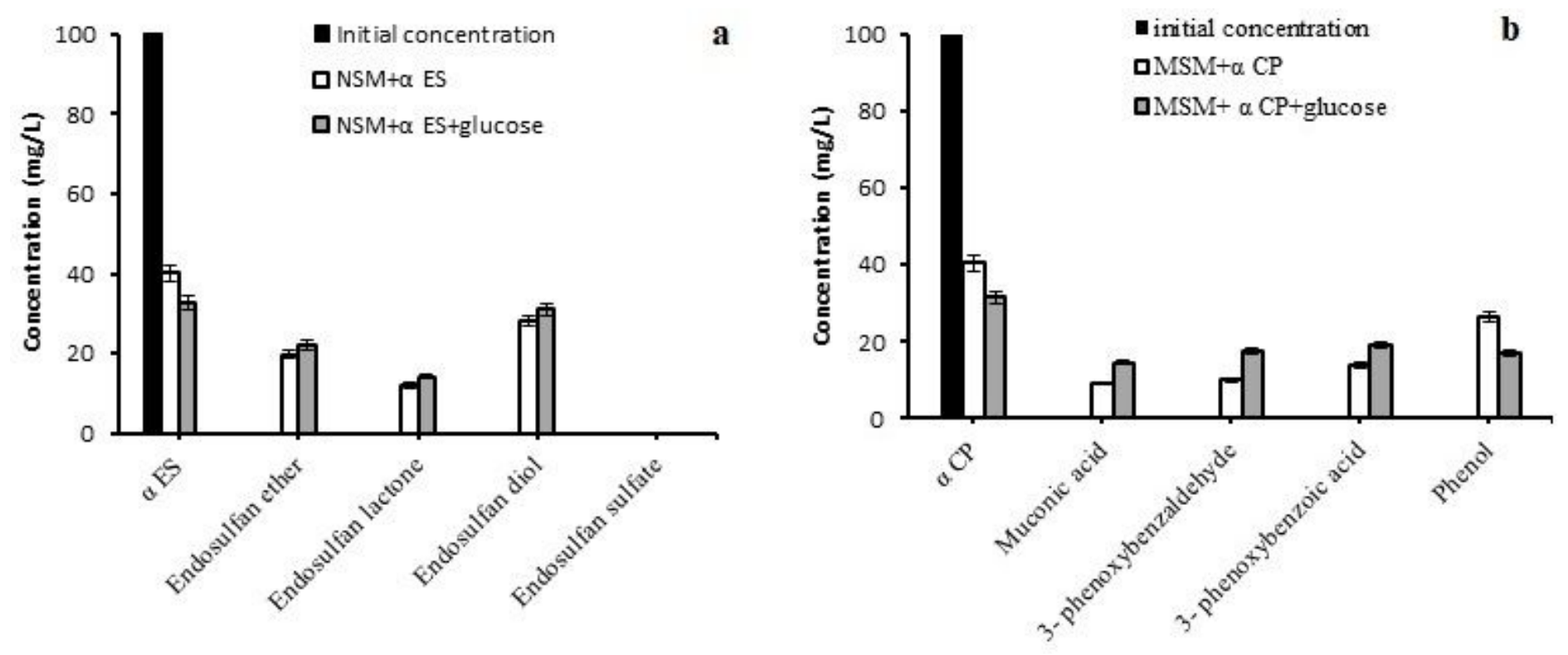

Figure 3

Biodegradation of a-endosulfan (a) and a-cypermethrin (b) in the presence and absence of glucose and its metabolites at 10 days.

\section{Supplementary Files}

This is a list of supplementary files associated with this preprint. Click to download.

- Graphicalabstract.png 